\title{
Breaking Ground: The LSU Community Playground Project
}

Dr. Marybeth Lima, Louisiana State University

Dr. Marybeth Lima is a professor in Biological and Agricultural Engineering at LSU and is also the director for the LSU Center for Community Engagement, Learning and Leadership. 


\title{
Breaking Ground: The LSU Community Playground Project
}

\begin{abstract}
The LSU Community Playground Project was formed in 1998 with regard to Biology in Engineering, a first-year, required design course in biological engineering, which is a servicelearning and communication intensive course. In this course, students are placed into groups of $3-4$, and each section of the course (usually 2-3 sections) is assigned to a local public school. Students collaborate with the students, staff, and administration at the school, and sometimes the broader community, to develop "dream playground" designs at the school, with the children, the true experts at play, at the center of the design process. Each student team completes an iterative playground design and presents it through a short oral poster presentation to the school community; a detailed technical report is also submitted to the instructor. After the semester is over, the faculty member in charge of the Playground Project works with a committed student team and the school community to consolidate the designs developed for each school into one, and to procure funds to build the playground, usually through a volunteer build process. Approximately $33 \%$ of students enrolled in the course volunteer to build the playground that they designed on paper. These efforts have resulted in 28 local playgrounds being constructed that serve approximately 10,000 children every school day. In this paper, the author will (1) present the service-learning model used to develop this course, including how this model evolved over time to better meet both student and community needs, (2) share pertinent data, including community engagement indicators, student retention, and percentage of alumni who are active in community engagement, and (3) discuss major lessons learned during the course of 15 years as a community engaged faculty member.
\end{abstract}

\section{Introduction}

Service-learning is defined as "a credit-bearing, educational experience in which students participate in an organized service activity that meets identified community needs and reflect on the service activity in such a way as to gain further understanding of course content, a broader appreciation of the discipline, and an enhanced sense of civic responsibility." (Bringle and Hatcher, 1995). Service-learning in higher education was pioneered by Ernest Boyer (1990, 1996) and by a number of others (Harkavay, 2004; Eyler and Giles, 1999; Zlotkowski, 1998) and is now generally recognized as an important part of higher education as evidenced by Campus Compact, the major society for service-learning in higher education, which boasts more than 1,200 university members.

Leah Jamieson pioneered service-learning in engineering through the Engineering Projects in Community Service (EPICS) program at Purdue (Coyle et al., 1997). This model features vertically integrated teams consisting of an equal number of freshman, sophomore, junior, and senior engineering students who take a course repeating times for semester credit and who work together on solving a significant community problem. The EPICS model has been expanded to include approximately 20 colleges of engineering nationally and internationally. Other long-term service-learning practitioners in engineering include John Duffy 
(http://www.compact.org/initiatives/consulting-corps/john-duffy/4386/) and Edmund Tsang (http://www.wmich.edu/engineer/ceee/coe.html); Tsang was the editor of the American Association of Higher Education's Service-Learning in the Disciplines volume on engineering in 2000 (Tsang, 2000). The first textbook on service-learning in engineering was published in 2006 (Lima and Oakes, 2006) and the journal entitled International Journal for Service Learning in Engineering, Humanitarian Engineering and Social Entrepreneurship (IJSLE) was founded in 2006. The Community Engagement Division of the American Society for Engineering Education was created in 2012 and now boasts over 300 members.

Service-learning continues to increase in the engineering profession. In this context, I am discussing the creation of a service-learning course, its evolution over time, and the outcomes of this course. This paper is intended to provide information for those who wish to initiate a service-learning engineering course and for those who endeavor to improve on an existing effort.

\section{The service-learning course: model and evolutions}

In 1997, I began teaching a first-year, biological engineering design course whose main purpose in the curriculum was to orient students to the major, to provide basic information on engineering design, and to increase retention of students by enabling them to build a community of learners (the opposite of a "weed out" course). Biological Engineering (BE) 1252: Biology in Engineering is a 2-credit hour (1 hour lecture, 3 hours laboratory per week) second semester freshmen core course. The description is as follows: effect of variability and constraints of biological systems on engineering problem solving and design; engineering units; engineering report writing; oral report presentation; laboratory demonstration of biological engineering analysis. The mean enrollment in this course is 50 students (enrollment has exceeded 60 students in the past four years).

Because biological engineering students are interested in many different problems at the intersection of biology and engineering, including those in environmental, bioprocessing, medical, and biotechnology arenas, the design project had to be engaging for this cross-section of interests. I also wanted to choose something that everyone was familiar with as their initial design experience in the curriculum. Playgrounds are an excellent artifact to design in lieu of these interests; additionally, playground safety standards are almost entirely trigonometry-based, which is important because all my students have been exposed to trigonometry, while a fraction of my first-year students are enrolled in calculus.

I decided to make this class a required service-learning course after seeing a lecture by Edward Zlotkowski in 1998 and becoming convinced of the research-based benefits to students who participate in service-learning; I worked closely with the LSU Center for Community Engagement, Learning and Leadership to help develop the service-learning component in my course. I used the best practices of service-learning and knowledge of service-learning models to fine tune the service-learning aspect of the course. These are as follows:

\section{Best Practices}

- Assign academic credit for learning, not for service 
- Uphold academic rigor

- Set learning goals for students

- Establish criteria for the selection of community service placements

- Provide educationally sound mechanisms to facilitate community-based learning

- Provide support for students as they engage in community-based learning

- Minimize the distinction between the students' community learning role and the classroom learning role

- Re-think the faculty instructional role

(CCELL Faculty Handbook, section 1.3, see

http://uiswcmsweb.prod.lsu.edu/ccell/Faculty\%20Resources/FAQ/item49383.pdf for more details on each best practice)

\section{Models}

There are two major types of service-learning models. In a placement model, students are assigned to a community partner or community agency, and by serving within that agency, they better meet their course objectives. For example, a childhood education student might tutor in a school setting to gain insight into the school setting and into education in a one-on-one framework, or a food science student might serve an hour a week at the food bank to gain greater insight into the importance of food accessibility and distribution within a community. Most students enrolled in a placement model at LSU spend at least 10 hours in their placement during the course of a semester.

In a project model, students work to create deliverable products that a community partner will use. For example, graphic design students might create logos and brochures for organizations like a food bank or the mayor's office of community engagement. In this model, the students, often working in a team setting, spend most of their time engaged in the creation of the product rather than in direct contact with the community agency. Most service-learning projects in engineering use the project model.

Finally, there are service-learning courses that are a combination of both placement and project models.

The following excerpt is from my syllabus and is used to orient students to the service-learning component of the course:

\section{Course approach.}

This is a service-learning course. Service-learning is defined as "a credit-bearing, educational experience in which students participate in an organized service activity that meets identified community needs and reflect on the service activity in such a way as to gain further understanding of course content, a broader appreciation of the discipline, and an enhanced sense of civic responsibility." (Bringle and Hatcher, 1995) 
project that concerns biological engineering and addresses a community need. This process is a mutual exchange of knowledge, information and service between the community (through community partners) and each of you.

This year, each lab section will be working in a group of 3-4 students to design a playground at a local, public elementary school. This playground will be based on the needs and wants of the true experts on play: the elementary school students enrolled at the school. Additionally, you will consider input from the school's faculty, physical education teacher, school improvement team, and possibly from parents and other members of the community. Each of these playgrounds will be designed by end of the semester, and will hopefully be constructed at some point in the future.

Section 1 will be working with xxx Elementary School.

Section 2 will be working with yyy Elementary School

Overall approach to service-learning project:

Weeks 1-4

- Learn about engineering design and the engineering design method

- Learn about designing playgrounds

- Learn about your group members and create policies for decision making and project management

- Information gathering on community partner and addressing community needs (meet with contact and community members, site visit)

Weeks 5-8

- Continue information gathering with community partners (second site visit, further discussions with community partners) and professional playground designers

- Generate preliminary designs

- Initial check on designs by instructor

Weeks 9-12

- Create and refine final design with input from instructor, community partners, and experts

Weeks 13-15

- Presentation of final design to school (through a poster that you will leave with the school)

- Completion of report/proposal of playground design

The course concludes with each partner school having 6-8 designs for their playground.

However, the school does not typically have the funding or expertise to move the process from a playground design on paper to a built design. I thus created a process to complete the designs 
that does not take place within the semester-long course. This feature is discussed in more detail below.

\section{Evolutions of the service-learning program}

The following four evolutions of The LSU Community Playground Project are, in my opinion, important components of the program's success.

Increasing focus on reflection and the concept of equal partners with knowledge. Focusing on these two areas drives students to develop the critical thinking skills and proper respect for the community that I believe are critical to the future of any engineer. Reflection, or metacognition, is the process by which students make sense of their experiences and understand them in larger contexts such as within their profession, within a community, and within society. As practicing professionals, we all practice reflection, but this process is so natural to us that it can be difficult to explain to a student how to develop this skill. I use the "what, so what, now what" reflection model to provide students with a framework for practicing reflection; I also provide plenty of opportunities for students to practice reflection through writing and conversation. Lima and Oakes (2006) is a textbook for service-learning in engineering, and contains a chapter on reflection. The second edition of this textbook will be published in June, 2013 and contains much more information on reflection, as well as practice reflection questions through each topic area in the textbook, so that students can develop and practice this skill throughout a service-learning project.

One area of focus of reflection for students involves the knowledge base that is available within a service-learning context. Most students come into the service-learning course with the assumption that the professor knows everything that they will use their knowledge to "help" a community that doesn't have knowledge. I encourage my students to think about servicelearning from the standpoint that every constituent has expertise and that together, we share our expertise to effect positive community change. I remind my students that the true experts in play are the children who play every day, not us. I remind my student that the true experts on the community with whom they are collaborating are the members of those communities who live and work there - school staff members are experts on the school and on the subject matter that the elementary school children are learning. I also focus on not using the word help, but using the word serve instead, as per the quote by Rachel Naomi Remen: "When you help, you see life as weak. When you fix, you see life as broken. When you serve, you see life as whole. Fixing and helping may be the word of the ego, and service the work of the soul."

Choosing the community partner. Initially, I chose a school because I had a connection with one of the school's teachers, and they were in need of a new playground. I chose the second school I worked with because they approached me after reading a newspaper article describing the first collaboration. After finishing two school playgrounds, I had become familiar with personnel in the school system and with the company that the school system contracted to complete all grounds and maintenance work, including playground maintenance. The person in charge of grounds and maintenance sent some of his staff to training to become Certified Playground Safety Inspectors (CPSIs). These staff established a scoring system for all school playgrounds based on need; they subsequently inspected all school playgrounds and used the rubric to compile the schools in ranked order of need from 1 to 50. I use this list to choose my community 
partners for each class. Using this approach, I have one community partner: the local public school system; and I collaborate with different schools each year. I also report to Chief Information Officer of the public school system to give reports on "state of playgrounds" and to ensure proper communication and collaboration is taking place to address this community issue.

The playground research and design team. As previously stated, when the service-learning course ends, each partner school is presented with numerous designs detailed through a poster presentation geared toward children and adults at the school. There are a number of steps between this stage and a completed playground as follows:

- Consolidate the designs into a single, agreed upon design (involves company that runs grounds/maintenance for school system, equipment placement)

- Design check (involves company that runs grounds/maintenance for school system)

- Obtain funds to build the playground (usually involves our team and the specific school)

- Write bid specifications for the design (written by us in conjunction with the company that runs grounds/maintenance for school system)

- Send out the bid documents and award the bid (run by the bidding/purchasing office of whichever organization has the funds, typically LSU or the school system)

- Construct the playground, either through a volunteer build (preferable) or through professional installation

Because there are no funds set aside within the school system to build or upgrade playgrounds, the fundraising portion of this process must also be addressed, and is usually the rate limiting step with these projects. When the project started, I did most of the grant writing to facilitate funds to build the playground. However, as the number of schools with designs completed increased at a faster rate than the playgrounds built, over time, I became a bottleneck in the process. Additionally, requests for playground collaborations come at a faster rate than I can keep up with them. These facts led to me recruiting a team of students, each of whom has completed the course, to work for me on a year-round basis on playgrounds. For me, the decision is not based on the grade in the course, it is based on how well student works with community partner: can they listen? Do they have the interest in playgrounds and the initiative to complete a project? Typically 4-8 students work in the group, with more established students teaching newer team members. They work on all the steps above, with one student as project leader for a single playground project, with 1-2 others assisting. Each student is leading one project. We have weekly meetings throughout the year to gauge progress. It is a great joy to work with this team of students - it is perhaps my favorite part of the entire process.

Risk management. The following protocol for the playground project was determined through multiple meetings with the LSU Office of Risk Management.

During the service-learning course, students are required to secure field trip insurance each time they leave campus to visit the partner school. This insurance, obtained through LSU, with oversight from the LSU Center for Community Engagement, Learning and Leadership, provides nominal coverage for students while they are engaged in any activities associated with the course. See https://sites01.lsu.edu/wp/riskmgt/triptravelservice for details. 
After the service-learning course is complete:

- Consolidate all student designs into one (playground research and design team and partner school)

- Design check (me and the company in charge of grounds/maintenance in the school system)

- Bid specifications (checked by organization that sends out the documents); there is a caveat within the specifications document that changes to the design can only be made to comply with playground safety standards.

- Awarding the bid: the company who receives the bid is liable for equipment malfunction and for any injuries that may occur due to the installation of such equipment, even if that installation was performed by volunteers.

- Volunteer installation. All volunteers sign a waiver of liability and are oriented to safety features on the site. Volunteers are not allowed to use power tools unless trained by the company overseeing the installation process.

- After the playground is in use: the grounds/maintenance company is in charge of maintaining the playgrounds. Any injury that occurs due to improper maintenance is the responsibility of the company.

Although LSU assured me that as a result of my employment, I would be covered if an injury on community-designed playground resulted in my being sued, I still carry liability insurance just in case. I do NOT use my PE license for this purpose (I am a PE in Agricultural Engineering, which is not specifically related to playground design); I use my CPSI license, for which I am a member of the National Recreation and Parks Association, which makes me eligible for liability insurance.

\section{Outcomes}

Six-year retention rate data was collected from the time that the service-learning component of the course was fully implemented (1999) until 2007 (students take the course as second semester freshmen, and so began their college careers in Fall 2006, representing the latest date at which 6year retention rate data is available). The overall retention rate of the cohort is $60.5 \%(244 / 403)$ --this percentage represents the students who graduated with a B.S. in biological engineering. There exists limited data for the course before it was taught using service-learning, but for the year prior to the implementation of service-learning (or active learning), the retention rate was $26 \%(6 / 23)$. The retention rate for the service-learning portion of BE 1252 is significantly higher than that of the LSU College of Engineering. There is no first year experience in the LSU College of Engineering.

Overall retention data of the playground research and design team was also determined; 23 students have served on this team; 20 were selected by me and three were assigned through the LSU Chancellor's Future Leaders in Research Program. This cohort consists of 12 women and 11 men; 9 students are ethnic minorities (5 African-American, 3 Asian, and 1 student of Middle Eastern descent). Seven students are currently enrolled, of whom 6 are currently serving on the team (three sophomores, one junior, and two seniors); of the 16 remaining students, 15 graduated (one left LSU without earning a degree). All graduating students except one completed a B.S. in 
biological engineering; the other student completed a degree in biological sciences and is currently enrolled in medical school. Of the 14 biological engineering graduates, 9 are currently practicing engineers. The other five entered graduate or professional school and are currently enrolled/employed as follows: two postdoctoral Fellows; one Ph.D. student, one masters student, and one student in medical school. The three students who were assigned to the team through the LSU Chancellor's Future Leaders in Research Program had the following outcomes: one left LSU without earning a degree; one is currently enrolled in biological engineering but left the team; and one graduated with a degree in biological sciences and is now enrolled in medical school.

From 1999-2012, the students in BE 1252 have designed 27 playgrounds in conjunction with local school communities; of these, 19 have been built; the vast majority of uncompleted playgrounds were designed within the last 1-2 years and are in the "rate limiting" step of the process: getting funding to construct the design. The playground research and design team has worked on 10 additional playground design projects, and of these, 9 have been constructed. Collectively, these 28 playgrounds serve more than 10,000 students every school day, and neighborhood children throughout the year. Approximately one-third of all students enrolled in the course return as volunteers to help build the playgrounds designs that were created through the elementary school - college collaboration.

Of the 28 playgrounds that have been constructed, 19 have been completed in the local public school system, 5 have been completed in the public school systems of parishes immediately surrounding Baton Rouge, and 4 others have been built for special populations (survivors of Hurricane Katrina, children who are deaf, and children who have cerebral palsy).

Our focus is the local public school system, which contains 50 elementary schools. Our collaboration with the school system has resulted in $38 \%$ of the total schools in the system having upgraded playgrounds. Currently, at the system level, approximately 10 schools have significant need for new playgrounds. Of these schools, we have completed 5 designs and need funding to complete them; there are also 5 schools with whom we have not yet collaborated.

Since changing the service-learning model from a project model to a combination project and placement model, students have contributed approximately 1500 hours of one-on-one reading instruction. Aggregate data from the group that tracks the success of the Reading Friends program indicates that students who are tutored through this program increase half a letter grade for every year that they are enrolled in the program (a student reading throughout the semester represents half a year of enrollment).

The biological engineering program used this course to meet several a-k outcomes during ABET accreditation in 2009. This service-learning component was used to successfully illustrate student mastery of the following outcomes:

(a) an ability to apply knowledge of mathematics, science, and engineering

(b) an ability to design a system, component, or process to meet desired needs within realistic constraints such as economic, environmental, social, political, ethical, health and safety, manufacturability, and sustainability 
(d) an ability to function on multi-disciplinary teams

(h) the broad education necessary to understand the impact of engineering solutions in a global, economic, environmental, and societal context

(j) a knowledge of contemporary issues

An alumni survey was conducted as part of accreditation activities; part of this survey asked former participants in BE 1252 about the relationship between community service and servicelearning, both before and after graduation. $71 \%$ of respondents participated in community service activities as undergraduates, while $34 \%$ of respondents currently participate in volunteer community service as graduates. In terms of participation in community service before graduation, $28 \%$ of respondents reported that taking BE 1252 made them more likely to participate in community service; $31 \%$ responded that taking BE 1252 may have made them more likely to participate in community service; and $28 \%$ reported that taking this course did not make them more likely to participate in community service. I believe that collecting further data on this relationship would be an interesting addition to the literature.

Several research projects have been completed in conjunction with BE 1252. A partial publication list is as follows:

- Lima, M. 2013. Building Playgrounds, Engaging Communities: Creating Safe and Happy Places for Children. LSU Press, Baton Rouge, LA. ISBN 978-0-8071-4980-5.

- Lima, M. 2012. Community at the Center of the Storm. Journal of Service-Learning in Higher Education. 1(1): 87-100.

- Strait, J. and M. Lima (Eds). 2009. The future of service-learning: new solutions for sustaining and improving practice. Stylus Publishing, Sterling, VA, ISBN 978-1-57922364-8.

- Lima, M. and W. Oakes. 2006. Service-Learning: Engineering in Your Community. Great Lakes Press, Okemos, MI., ISBN 1-881018-94-6.

- Ropers-Huilman, B., Carwile, L. and M. Lima. 2005. Service-learning in Engineering: A Valuable Pedagogy for Meeting Learning Objectives. European Journal of Engineering Education 30(2): 155-165.

- Lima, M. 2004. Service-Learning in Engineering through K-12/University Partnerships: Reflections from five years in the trenches. Journal of Higher Education Outreach and Engagement 9(2): 159-170.

- Eppert, C., Ropers-Huilman, B. and M. Lima. 2003. Engendering Respect in a ServiceLearning Community: Teaching and Learning in a Multidisciplinary Partnership. Scholar-Practitioner Quarterly 4(1): 89-104.

In terms of the research conducted in conjunction with the LSU Community Playground Project, my research agenda evolved in a somewhat similar manner to the ways in which the playground project evolved. My initial efforts in terms of research and publication involved "getting the word out" to other faculty practicing engineering service-learning. I connected with an educational researcher early in the process to properly execute quantitative and qualitative research on proving the value of the service-learning experience for engineering students (see the 2003 and 2005 publications previously listed). My scholarly work has shifted toward longer 
publications (books) that address broader issues in service-learning (see 2009 publication), and in service-learning in engineering (see 2013 publication). A wise mentor once told me, "Once you reach full professor (in terms of research), remember to stop focusing on numbers and start focusing on impact." Currently, I am a lot more interested in broader research questions that I believe get at "the impact" in engineering service-learning, such as:

- How do we create truly reciprocal partnerships in engineering service-learning?

- How can we encourage the engineering profession to see all "ways of knowing" (especially those that are community-based and/or non-technical) as valued and integral parts of the community-based design process?

- What are best practices in terms of teaching our students and ourselves the critical importance of contextual listening?

- How do we use our engineering skills to tackle complex societal problems?

\section{Conclusion: lessons learned as a community-engaged faculty member}

When I first ventured into service-learning, I had outcomes for my students in mind. I was looking at the research compiled by Eyler and Giles (1999) which showed that service-learning resulted in deeper understanding of course content and an increased ability to apply material that they learn to real-world problems (among other things). As I engaged with my service-learning office and with my community over time, I learned that there were more components to a service-learning program than students. Students are really important, but there's also the instructor, the university, the community partner, and the broader community to consider. Students are one important player in a team of players needed to truly create positive impact in the community. Thus, my focus has shifted from a myopic view of students only to a more holistic view involving my entire community and the incredible impacts we have when we do ordinary things together.

For years, I used the project model of service-learning in which the students' service-learning deliverable was a playground design. I decided to change to a combination model when my assessment of students' designs identified a missing component. I began to stress to students the importance of expressing "the soul of the community" in their playground designs. I claimed that being able to express the soul of the community in the design is what would separate them from other engineers, and that it would be what would make the playground design for that particular school unique, because the playground design should be a unique reflection of the unique community it will serve. My students typically looked at me like I had three eyes when I had this conversation. Most of the time, they would report that they had captured the soul of the school community by prominently featuring the school's colors and/or mascot in their design. I had an epiphany after having a conversation with the students in which I asked them if the soul of LSU was purple and gold and tigers (and in which, thankfully, most of them said no, and managed to articulate what they felt was the soul of the LSU community): how could I expect students to capture the soul of their school community when they spent almost no time engaged in that community? This epiphany is what led to my changing the service-learning model I was doing to a combined project-placement model; the only way that students will truly understand the community with whom they are collaborating to create a design is to spend significant time engaged within that community. Based on assessment of student final reports, the students now 
understand "the soul of the community" and are able to propose design features beyond school colors and the school mascot.

Finally, learned about myself as a community-engaged faculty member; I met the best people on campus when I connected with my university's service-learning office. I "joined the trench" in my community of people who doggedly work to make our city a better place to work and live for everyone. This process has grounded me and has provided much more meaning to what I am doing as an engineering faculty member. I have had to be creative to frame my work as scholarly (by publishing it) and to negotiate the complex policies and procedures within my university that are necessary but are not standardized to significant work with community partners.

I have learned to be a better citizen. For example, when I added the reading friends placement model to the course, I initially wanted the students to tutor math instead of reading. However, the community agency that administered both reading and math tutoring programs for our public school system stated that reading volunteers were more needed than math volunteers, and also that math kits (which were $\$ 80$ each) were in short supply. For these reasons, I required the reading program rather than the math program. Because garnering funding for the playgrounds is so difficult, I began a seminar program in which teams of people from partner schools (parents, teachers, etc.) learn from me and from guest lecturers how to fundraise and write proposals to fund playgrounds. These efforts have enabled three schools to complete their playgrounds. My ultimate goal is to upgrade all the public school playgrounds in my community.

Truly addressing a community issue requires planning, assessment, evaluation, and action; reflecting on this process has enabled me to be a better citizen to my community and a better instructor for my students.

\section{References}

Boyer, E. (1990, re-released 1997). Scholarship reconsidered: Priorities of the

professoriate. Princeton, NJ: Carnegie Foundation for the Advancement of Teaching.

Boyer, E. (1996). The scholarship of engagement. Journal of Public Service and Outreach, 1 (1), 11-20.

Bringle, R. and J. Hatcher. 1995. A service-learning curriculum for faculty. Michigan Journal of Community Service Learning, 2: 112-122.

Coyle, E., Jamieson, L. and L. Sommers. 1997. EPICS: A Model for Integrating ServiceLearning into the Engineering Curriculum. Michigan Journal of Community Service Learning. 4: 81-89.

Eyler, J. and D. Giles. 1999. Where's the Learning in Service-Learning? Jossey-Bass: San Francisco, CA, ISBN 0470907460 
Harkavy, I. (2004). Service-learning and the development of democratic universities, democratic schools, and democratic good societies in the 21 st century. In New perspectives on servicelearning: Research to advance the field (M. Welch \& S. Billig, eds.) (pp. 3-22), Greenwich: Information Age Publishing.

Lima, M. and W. Oakes. 2006. Service-Learning: Engineering in Your Community. Great Lakes Press, Okemos, MI., ISBN 1-881018-94-6 (book was purchased by Oxford University Press in 2011; $2^{\text {nd }}$ edition will be published in June, 2013).

E. Tsang, Editor. 2000. Projects That Matter: Concepts and Models for Service-Learning in Engineering, AAHE's Series on Service-Learning in the Disciplines. AAHE Press,

Zlotkowski, E., Ed. 1998. Service-Learning in the Disciplines. 20+ volume series on servicelearning in various professions; entire series available at http://styluspub.com/Books/SearchResults.aspx?str=service-learning+in+the+disciplines. 